\title{
THE COURSE OF SOCIAL SECURITY SPENDING WITHIN THE PROCESS OF SOCIETY 5.0
}

\author{
Muhammet ŞAHIN ${ }^{1}$
}

\author{
Hamdi Furkan GÜNAY²
}

\begin{abstract}
Technological developments have left indelible impacts on the economy all along the line. Every novel invention realized changes production processes rapidly, which concomitantly transforms social life. One of the most apparent examples of this is the First Industrial Revolution emerged in the $18^{\text {th }}$ Century. Subsequent to this development which was considered as the beginning of production in the factory environment, the second industrial revolution based on automation (First half of $20^{\text {th }}$ Century) and the third Industrial Revolution based on electronics (last quarter of the $20^{\text {th }}$ century) were realized. Finally, the Fourth Industrial Revolution (Industry 4.0) process was initiated by Germany in 2011. In line with this process in which cyber-physical systems and robotic technologies are expected to prevail, Super-Smart Society (Society 5.0) model was developed by Japan in 2017. Both Industry 4.0 and Society 5.0 implementations are expected to have a significant impact on economic and social life and to change both labor and Welfare State practices fundamentally. It is also possible that these aforementioned developments may have an impact on social security system of the government. Likewise, the emergence of extensive unemployment condition due to robotic technologies and training for adaptation of available labor force to the new technologies may lead to redesign of the social security system. The aim of this study is to demonstrate the possible impacts of the Industry 4.0 and Society 5.0 processes on social security expenditures. The basic result obtained from the study; unemployment increase and training activities for the labor-force increases social security expenditures, but however digitalization process in Welfare State implementations may be expected to decrease social security expenditures in the long-run depending on efficiency and effectiveness increases in the government.
\end{abstract}

Keywords: Industry 4.0, Society 5.0, Welfare 4.0, Super Smart Society, Social Security Spending, Welfare State.

JEL Code: H55, O33, 138.

\section{Introduction}

Scientific and technological changes are rapidly transforming the production structures. Within the historical process, humanity has experienced three industrial revolutions. The first one emerged in the $18^{\text {th }}$ and $19^{\text {th }}$ centuries and the bases of the factory production were laid in this process (More, 2000). Second Industrial Revolution started to create influences beginning from the first half of the $20^{\text {th }}$ century and automation based production become possible starting from these years (Atkeson \& Kehoe, 2001). The process of third industrial revolution based on microchip technologies has begun since the 1960-1970s (Kaplinsky, 2005).

It is accepted that the industry model which is called as the Fourth Industrial revolution and in which cyber-physical systems and smart factory applications are dominant in production started

\footnotetext{
1 Dr. Faculty Member, Gümüşhane University, Faculty of Economics \& Administrative Sciences, sahin@gumushane.edu.tr (corresponding author)

2 Res. Asst., Gümüşhane University, Faculty of Economics \& Administrative Sciences, hamdifurkangunay@gumushane.edu.tr
} 
in 2011. The model is predominantly based on robot technologies and unmanned production processes. Industry 4.0 model was reflected in the social area with Society 5.0. The main assertion of this application is to increase life quality within a social structure based on electronics.

On the other hand, it is expected that the automation process which will be generated by industry will make a change in social security expenditures of the government. The aim of this study is to determine direction and impact of the aforementioned change. Thus, the study includes possible changes in production and social structure and possible impacts of these social welfare expenditures of the government.

\section{Society 5.0, a Reflection of Industry 4.0}

Fourth industrial revolution (Industry 4.0) asserts to be a novel method of production. Industry 4.0 model, in which new technologies such as Internet of Things (IoT), Internet of Services (IOS), cyber-physical systems, artificial intelligence, robots, big data and cloud computing are used, represents three basic components for production processes. The first one of these is the digitalization of production and it includes information systems for production and management planning. The second component is called as the automation and includes systems for collecting and processing data from production lines. The third component which is known to be automatic data change aims to connect production areas to large scale supply chains (Roblek et. al., 2016).

Digitalization of production processes transforms social areas. The most concrete form of this is Super Smart Society Model which is called as Society 5.0. The concept of Society 5.0 includes historical development stages of humanity so far. These are respectively; Hunter-Collective Society (Society 1.0), based on the beginning of humanity, Agricultural Society (Society 2.0) which approximately emerged in 13000 BC, Industial Society (Society 3.0) of the eighteenth century, Information Society (Society 4.0) and Super Smart Society (Society 5.0) processses. Society 5.0 applications depend on the idea that social problems will be recovered depending on electronic developments and human beings will have better life standards in the future. The basic tools of the model are artificial intelligence, robot technologies, internet of things and big data applications (Fukuyama, 2018).

\section{Social Security Spending within the Process of Society 5.0}

\subsection{The Impact of Developments in Automation Technologies on the Employment}

Society 5.0 and Industry 4.0 processes are primarily based on robotic technologies, autonomous devices and artificial intelligence applications. In case the human factor in production completely disappears, it seems inevitable that the problem of unemployment will become highly evident and as a result of this there will be an increase in social security spending of the government such as unemployment and poverty benefits. According to the researches; it is expected that job losses due to automation will exceed $35 \%$ in manual and routine tasks and literacy and social skill trainings which are considered to have the minimum level of losses will be incurring losses at a level of almost 10\% (PWC, 2018: 15-18). 


\section{Graph 1. Number of Robots Used in Manufacturing Industry ('000)}

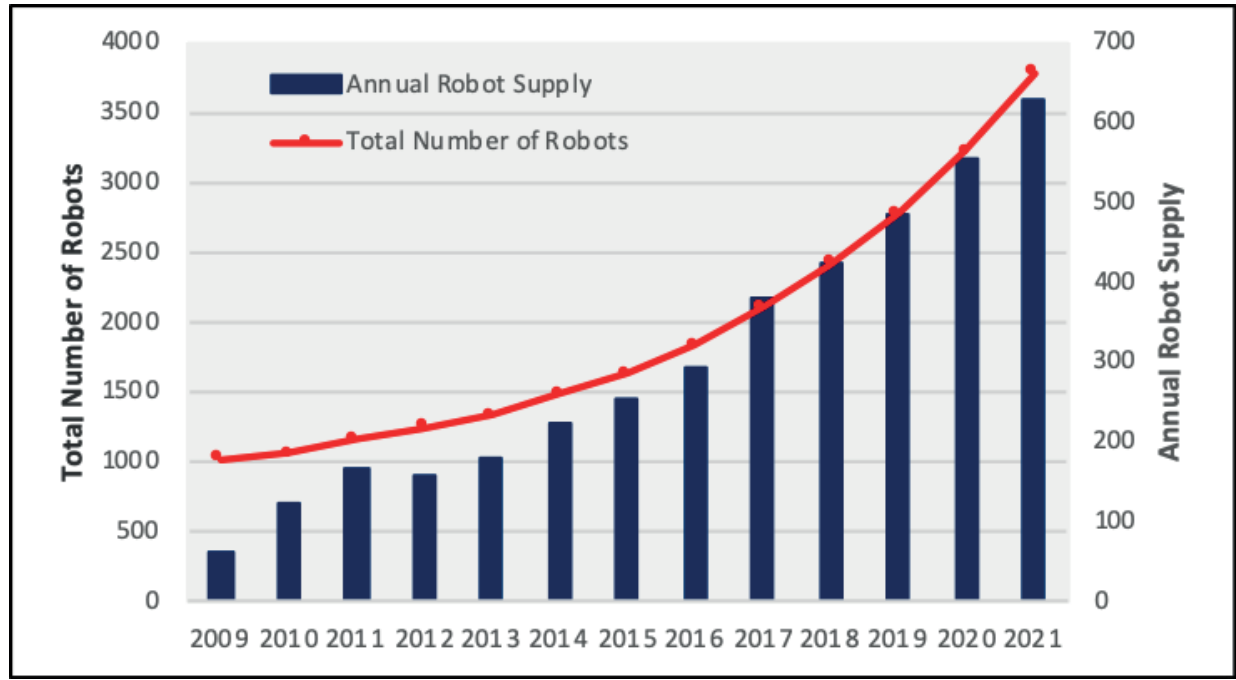

Source: International Federation of Robotics, 2018.

Possible contractionary impact of the technological developments on the employment may lead an increase in the social security expenditures of the government for unemployment. Past experiences reveal that there is a natural increase in unemployment benefits in years when there is an increase in unemployment. Furthermore, in case of unemployment arising due to developments in automation technologies, as the unemployment itself may become permanent, high amount of social security expenditures may also become permanent. One of the current debates on the issue is about the payments called as citizenship income (universal basic income). These payments which were primarily made in US and Canada between 1960 and 1980 are now implemented at a limited level (Lehto, 2018: 21-22). However, as a result of digitalization process in economic and social life and resulting widespread unemployment situation (McKinsey Global Institute, 2017: 2), enlarging the scope of citizenship income payments and an increase in the amount paid per capita may be added to the agenda.

\subsection{Training on Adaptation of Labor Force to New Technologies}

Production level is expected to increase depending on efficiency increase generated by robotics technologies and automation-based activities becoming widespread in the economy (Herčko et. al., 2015). However, this will be possible through a good training received both by current employees and future generations in order to adapt changes in technology (Müller et. al., 2018: 7-8).. Automation process will most negatively affect individuals with low education level and have a relatively less negative effect on individuals with high education level. It is inevitable that developments in robotic technologies will transform almost every profession and depending on this it will be creating pressure on employment. However, individuals with low education level will incur the highest level of this pressure. 


\section{Graph 2. Low-Educated Persons at Risk of Losing Their Jobs (\%)}

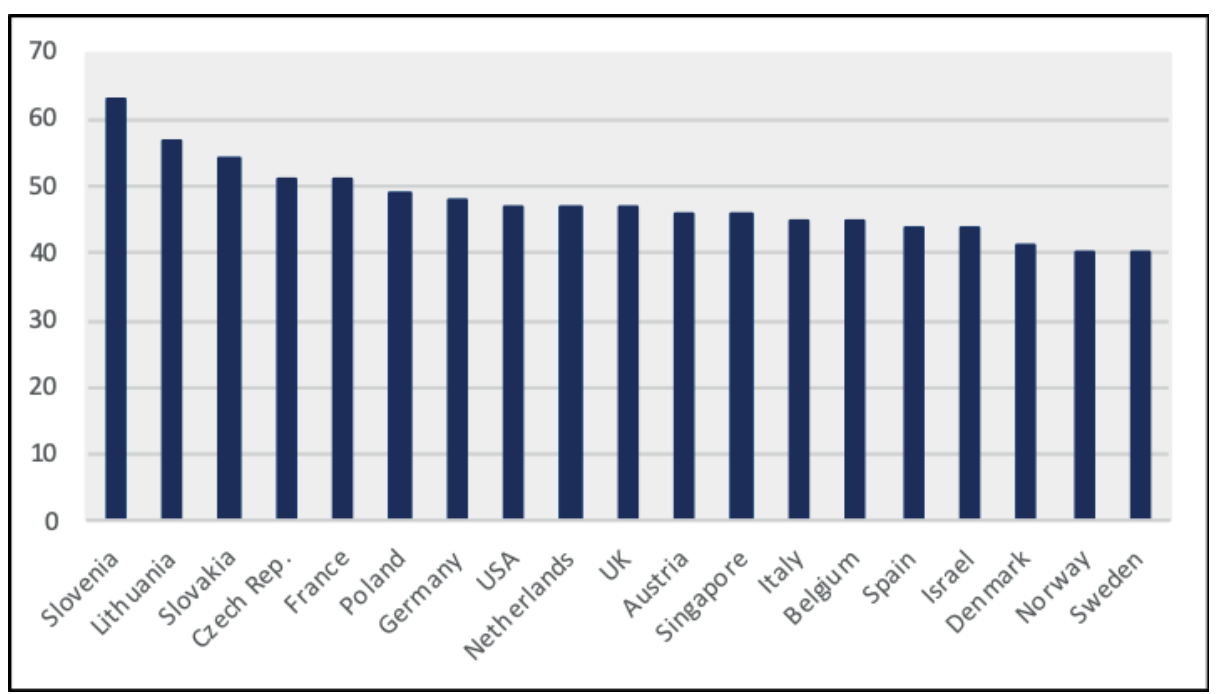

Source: PWC, 2018: 32-33.

Unemployment level of those with low training levels results the necessity of vocational training for these to be implemented more actively. However, this education should not only be restricted with school. The school is the place where the basic knowledge required for the individual in both social and professional life is taught. In today's contemporary world where continuously changing technology and increasingly automated production processes are gaining importance, after-school education should also be maintained (Rath, 2017). The changing aspect of professional specialization may require more social security expenditure by public authorities for vocational training.

\subsection{Welfare 4.0 Applications: Digital Transformation in Social- Welfare State}

Digital transformation in economic and social structure effects governmental institutions and their way of functioning. In the background of the digitalization in the government, there are underlying motivations such as getting rid of the present cumbersome bureaucratic structure, improving service quality and improving the performance of the public sector. Digital applications are expected to improve as to generate e-welfare model in the future and to realize Welfare 4.0 applications as an extension of Industry 4.0 process (Buhr, 2017). As well as this, the impact of Welfare 4.0 applications primarily on social security expenditures has a complicated appearance and it can be expected that in case the effectiveness and efficiency as a result of the digitalization process is higher than total amount of infrastructure and staff costs of the process, it can make a positive contribution to the reduction of public sector financing burden (Buhr \& Stehnken, 2018).

\section{Conclusions}

Application Industry 4.0 which makes a fundamental change in the production process and application Society 5.0 which is its reflection on the social area are expected to have an impact on social security spending of the government. First of all, it is estimated that robotization process in production will increase unemployment rates. As a result of this, an increase in unemployment payments of the government and widely-use of the application of citizenship income can be added to the agenda. Secondly, labor-force which is not ready to technological 
changes should give more importance on robotic processes adaptation training. It is possible that these training services for the workers may increase vocational training expenditures. Finally, as a follow-up of digital transformation in the government, it is projected that electronic welfare government applications will become widespread. This new model called Welfare 4.0 may increase expenditures due to infrastructure development and trained staff requirement and it is aimed to assist to decrease these aforementioned expenditures over public efficiency. Thus, in automation society of the future, it is possible to say that unemployment benefits and vocational expenditures may increase public expenditures and Welfare 4.0 applications may decrease these expenditures if carried out effectively.

\section{References}

Atkeson, A. \& Kehoe, P. J. (2001). The Transition to a New Economy After the Second Industrial Revolution, Federal Reserve Bank of Minneapolis Research Department Working Paper No. 606.

Buhr, D. (2017). “What about Welfare 4.0?”, CESifo Forum, 18 (4), pp. 15-21.

Buhr, D. \& Stehnken, T. (2018). Industry 4.0 and European Innovation Policy: BigPlans, Small Steps, Germany, Friedrich-Ebert-Stiftung.

Fukuyama, M. (2018). "Society 5.0: Aiming for a New Human-Centered Society", Japan SPOTLIGHT, 220, pp. 47-50.

Herčko, J., Slamková, E. \& Hnát, J. (2015). "Industry 4.0 as a Factor of Productivity Increase", TRANSCOM 2015, 22-24 June, Žilina.

International Federation of Robotics (2018). World Robotics 2018, Frankfurt, IFR.

Kaplinsky, R. (2005). "Technological Revolution and the International Division of Labour in Manufacturing: A Place for the Third World?", Technologyand Development in The Third Industrial Revolution, (Ed.) Kaplinsky, R. \& Cooper, C., London, Frank Cass, pp. 5-35.

Lehto, O. (2018). Basic Income Around the World: The Unexpected Benefits of Unconditional Cash Transfers, UK, Adam Smith Research Trust.

McKinsey Global Institute (2017). Jobs Lost, Jobs Gained: Workforce Transitions in a Time of Automation, USA, McKinsey Global Institute.

More, C. (2000). Understanding the Industrial Revolution, London, Routledge.

Müller, J. M., Kiel, D. \& Voigt, K. (2018). "What Drives the Implementation of Industry 4.0? The Role of Opportunities and Challenges in the Context of Sustainability", Sustainability, 10 (1), pp. 1-24.

OECD (2018). Employment Outlook, Paris, OECD.

PWC (2018). Will Robots Really Steal our Jobs? An International Analysis of the Potential Long Term Impact of Automation, UK, PWC.

Rath, O. (2017). From Industry 4.0 to Adult Education 4.0, European Commission Electronic Platform for Adult Learning in Europe, https://ec.europa.eu/epale/en/blog/industry40-adult-education-40, (22.12.2018).

Roblek, V., Meško, M. \& Krapež, A. (2016). “A Complex View of Industry 4.0”, SAGE Open, 6 (2), pp. 1-11. 